\author{
A.Sh. Kazhikenova, D.B. Alibiyev, E.S. Ibrayeva \\ Ye.A. Buketov Karaganda State University, Kazakhstan \\ (E-mail: aigul-kazhikenova@mail.ru)
}

\title{
Efficiency of applying cluster-associated model of viscosity of liquid metals
}

\begin{abstract}
To describe the viscosity up to the temperature transcendental polynomials with four or five adjustable parameters is often used, which devoid of physical meaning. As it is known, the extrapolation of these approximating dependencies is impossible more than for $25 \%$ of the investigated interval in view unavoidable appearance, it is main characteristic of such polynomials, which are completely contrary to the monotonously decreasing character of the temperature dependence of viscosity. Usually, the experimental points are for the low-temperature region adjacent to the melting point, and especially for high-refractory metals. Meanwhile, the viscosity of each metal strongly depends on the temperature and when it get changed from the melting point to the boiling point decreases about four times. The aim of our research is to develop a generalized cluster-associated model of viscosity of liquid metals based on the concept of chaotized particles according to the degree of clusters association. In this work temperature dependence of viscosity according to the concept of the randomized particles is considered. Models of viscosity dependence on temperature taking into account various maintenance of particles are analysed: crystal-moving, fluid and steam-moving particles. The new cluster model of viscosity temperature dependence allowing to reveal behavior of viscosity in the wide range of temperatures is offered. Applicability of this model on the example of indium fusion is shown.
\end{abstract}

Keywords: viscosity, chaotized particles, the degree of clusters association, cluster-associated model, liquid metals, reference point, crystal-moving particles, the temperature dependences of the viscosity.

\section{Introduction}

In recent years, due to the changing conjunction on the market of non-ferrous and rare earth metals is increasing interest in the study of their physico-chemical properties such as viscosity, plasticity and fusibility and others. In this connection, measurement of physical properties should be considered as a priority of experimental study the structure of real metallic melts.

The melt viscosity is of great practical importance in metal industry. At the same time, the study of the viscosity of molten metal is of great scientific interest, since the viscosity is the most structure-sensitive characteristics of the melt, which gives an idea of the internal forces of interaction of particles.

Expanding the use of liquid metals as working fluids and coolants in nuclear power engineering, chemistry, space technology and other industries, for the needs of metallurgical production and new materials technology make the task of research of their thermal properties, particularly viscosity, urgent. Previous studies found that the temperature dependence of the viscosity is determined by the structure of metals, inter particle connections and interactions between particles [1-3]. This relationship is based on the following theories: theory with effective inter-ion potential; electron theory to the calculation of the generalized pseudo potential; theory based on the methods of quantum chemistry; the theory of quasi-crystalline liquid (Fraenkel equation); semi-empirical model containing two or more adjustable parameters.

Disadvantages of the above theory is that they work in a very narrow temperature range, contain adjustable parameters, which are often no physical meaning. Thus, the main reason for the error correlation temperature dependence of viscosity is that all models of the main studied characteristics (pseudo- or pair potential) either are not changed by increasing temperature, or the models are valid only within a narrow temperature range, thereby not allowing to describe the behavior liquid generally range from melting point to the boiling point, or even to a critical point, ie in the full range of liquid on the basis of continuous change of the status of quasi-crystalline to quasi-gaseous.

\section{The methodology of the research}

Employees of the Chemical and Metallurgical Institute J. Abisheva, Doctor of technical sciences, Professor V.P. Malyshev and Doctor of technical sciences A.M. Turdukozhaeva proposed a new approach based on the Boltzmann distribution. According to this approach, all three aggregate states can be viewed from the perspective of subordination Boltzmann distribution and to connect virtually every state with important characteristics of matter on the basis of excess or excess energy barriers melting and boiling. As in all cases con- 
sidered particles, differing only in the amount of energy of chaotic motion, then their union and differential display can be described as the concept of chaotized particles $[4,5]$.

According to the concept of chaotized particles, crystal sliding and steam sliding, liquid sliding particles are present in each of the states of aggregation of matter. However, by increasing temperature, and overcoming various barriers of energy chaotization of ratio of the particles shares changes. Virtual education and the statistical presence of each of the three types of chaotized particles in each aggregate state allows by their balance to determine the role of each species in a particular state of various processes. The authors of the concept of chaotized particles proposed three formulas of temperature dependence of viscosity with the influence of the three classes of chaotized particles. The temperature dependence of the viscosity under the influence of crystal-sliding particle is given by:

$$
v_{1}=v_{r} T_{r} / T
$$

and formula crystal-sliding and liquid-sliding particles taken into consideration:

$$
v_{2}=\frac{v_{r} T_{r}\left[\exp \left(-T_{m} / T_{r}\right)-\exp \left(-T_{b} / T_{r}\right)\right]}{T\left[\exp \left(-T_{m} / T\right)-\exp \left(-T_{b} / T\right)\right]} .
$$

Under the influence of all the three types of the temperature dependence of the viscosity of the particle is described by the formula:

$$
\mathrm{v}_{3}=\frac{v_{r} T_{r}}{T} \exp \left(\frac{T_{m}}{T}-\frac{T_{m}}{T_{r}}\right) .
$$

In formulas (1)-(3): $T$ - temperature; $T_{m}$ - temperature of melting; $T_{b}$ - temperature of boiling and $v_{r}, T_{r}$ - viscosity and temperature in the reference point.

The proposed equations should be considered as an alternative to existing models of metals viscosity. Extensive testing of these models on the available reference of materials on the viscosity of metal melts allowed to establish the adequacy of the reference data of any of the three species of the proposed models. But the testing necessity of each three models and selecting of the most appropriate complicates the data processing procedure. This made more detailed consider the nature of the liquid state, while remaining within the concept of chaotized particles.

In each of the three states of matter particles chaotized, named crystal, liquid and steam sliding, generally create a more or less orderly set. The concept of chaotized particles based on the virtual presence of each of the three classes of particles in the solid, liquid and gaseous states of matter. Thus, in the solid state, although the crystalsliding particle as a whole and provide along-range order of Communications and stability of the crystal, their presence in the lattice is the exchange with more energy particles-liquid sliding and steam sliding -and there foreshort-lived, the virtual, with ever-changing mosaic of units and vacancies in each cluster formation.

Each individual particle according to the Boltzmann distribution for a short period of time that depends on extremely high frequency vibrations and binary collisions, the order of $10^{12} \mathrm{~s}^{-1}$, has time to visit all three of its guises. We can say that in the solid state virtually continuously it contains liquid and gaseous state. This virtuality is also characteristic of the liquid and gaseous states, i.e. we can talk about the virtual presence of a solid and gas in the liquid, solid and liquid in gaseous one.

According to the concept of randomized cluster of particles-this is a form of a probability of the existence of various low-energy complexes of the crystal-sliding particles. Calculations of equity and quantitative content of clusters to moles substance at the melting point and boiling point indicate that the concept of randomized particles allows to quantify the formation of clusters with their distribution by number of particles in the fluid at any temperature. The yield on the correlation of viscosity with an average number of particles in a cluster is crucial because it points directly to the lack of considering only the elementary clusters in the case of significant discrepancies with the experimental data on the viscosity. Probably a strong dependence on the temperature, in addition to the diluting effect of liquid sliding and steam sliding particles can be explained by the formation of associated or aggregated elementary clusters, the destruction of which with the temperature rising occur in parallel with the destruction of elementary clusters, which creates the effect of a stronger influence of temperature on the viscosity in the case of the formation of such associations or aggregates.

Therefore, we believe it is necessary to strengthen the fragment $\left(T_{r} / T\right)$ the basic model (1) by raising the probability of an elementary event equal to the number of colliding particles:

$$
\mathrm{v}=\mathrm{v}_{r}\left(T_{r} / T\right)^{a} \text {. }
$$


Here indicator $a$ association degree It makes sense to measure a degree $n$-particle clusters.

A detailed theoretical study of the temperature dependence of viscosity model of liquid metal according to the degree of association of clusters is given in works $[4,5]$.

\section{The results of research}

To pre-test of the applicability for justifying the generalized semi-empirical model of the viscosity of liquid metals on the concept of randomized particles we used well-known experimental and approximation data.

Recieved more generalized form of the temperature dependence of the viscosity can be used to calculate the activation energy of the viscous flow of the melt in combination with Fraenkel equation which is derived for the dynamic viscosity:

$$
\eta=A \exp \left(\frac{U}{R T}\right)
$$

Here $A$ and $U$ are respectively constant pre-exponential factor and the activation energy of viscous flow, the meaning of which is interpreted by different authors, depending on the intended nature of the interparticle interaction and quasi-crystalline structure of a liquid [6].

As the kinematic viscosity is related to the dynamic viscosity of the formula $v=\eta / \rho(\rho-$ melt density), then, because of the very weak dependence of density on temperature, can be directly replaced in the equation (5) $\eta$ to $v$, respectively, adjusting the parameters $A$ and $U$ by $A^{\prime}$ and $E_{a}$ :

$$
\mathrm{v}=A^{\prime} \exp \left(\frac{E_{a}}{R T}\right) .
$$

It should be noted that although the selection of the reference point is not critical, it expedient to fix near (but not at) crystallization, as at lower temperatures, the viscosity is determined more reliably and has the highest value. In the crystallization point itself because of the possible presence of an unspecified number of the equilibrium solid phase viscosity of the emulsion will be inflated against viscosity of the pure liquid state.

Here is the applicability of the proposed model by calculating the viscosity of indium. Indium [6] shows the values of $T_{m}=429,56 \mathrm{~K}$ and $T_{b}=2273-2373 \mathrm{~K}$ (average $2323 \mathrm{~K}$ ). It also contains data on the kinematic viscosity, which compared with calculated by model $v(1)-v(4)$ (see Table 1 , Fig.). The reference point is a point with $T_{r}=443 \mathrm{~K}$ and $\mathrm{v}_{r}=2,433 \cdot 10^{-7} \mathrm{~m}^{2} / \mathrm{s}$.

Table 1

Comparison of experimental [6] and calculated by models $v(1)-v(4)$ data by the kinematic viscosity of indium, $v \cdot 10^{7}, \mathrm{~m}^{2} / \mathrm{s}$

\begin{tabular}{|c|c|c|c|c|c|c|}
\hline$T$ & $v(\exp )$ & $v(1)$ & $v(2)$ & $v(3)$ & $a$ & $v(4)$ \\
\hline$T_{m}=429.6$ & - & 2.509 & 2.582 & 2.586 & - & 2.506 \\
\hline 443 & 2.433 & 2.433 & 2.433 & 2.433 & - & 2.433 \\
\hline 573 & 1.809 & 1.881 & 1.545 & 1.510 & 1.152 & 1.901 \\
\hline 673 & 1.542 & 1.602 & 1.206 & 1.150 & 1.091 & 1.629 \\
\hline 773 & 1.392 & 1.394 & 0.995 & 0.922 & 1.003 & 1.427 \\
\hline 873 & 1.288 & 1.235 & 0.853 & 0.766 & 0.938 & 1.270 \\
\hline 973 & 1.203 & 1.108 & 0.751 & 0.653 & 0.895 & 1.144 \\
\hline 1073 & 1.142 & 1.004 & 0.676 & 0.568 & 0.855 & 1.042 \\
\hline 1273 & 1.069 & 0.847 & 0.573 & 0.450 & 0.779 & 0.884 \\
\hline$T_{b}=2323$ & - & 0.464 & 0.374 & 0.212 & - & 0.497 \\
\hline$R$ & - & 0.981 & 0.143 & $<0$ & - & 0.986 \\
\hline
\end{tabular}

The average value of $\bar{a}=0,96$. Although India has a sufficient amount of experimental data, $\bar{a}<1$ due to the fact that it is a chemical analog of gallium and has good fluidity. The homogeneity of the received set for a followed by Nalimov criterion: $S(x)=0,405 ; \underset{\max }{r_{\min }}=0,514<r_{c r}=2,004$. 


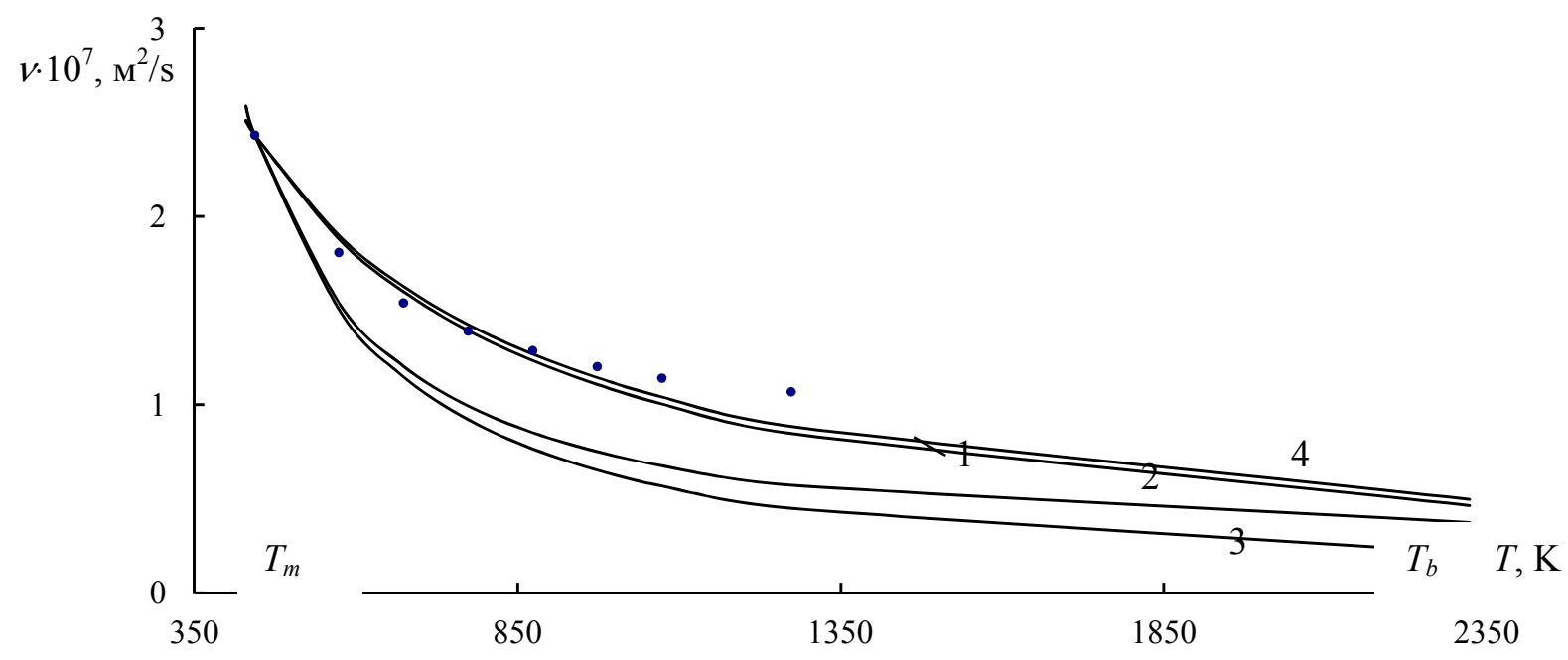

$v$ - the kinematic viscosity; $T$ - temperature; points - experimental data [6]; 1 - model (1); 2 - according to (2);3 - to (3); 4 - to (4)

Figure. Dependence of kinematic viscosity of indium on temperature

Given the degree of association with the cluster reference point in the model (4) can be used as a generalized model indium melt viscosity in the complete range of temperatures near the melting temperature of $T_{r}=443 \mathrm{~K}$ on the kinematic viscosity

$$
\mathrm{v}=8,389 \cdot 10^{-5} / T^{0,96} \pm 3,06 \cdot 10^{-9}, \mathrm{~m}^{2} / \mathrm{s} .
$$

In this temperature range is calculated activation energy $E_{a}=4681 \mathrm{~J} / \mathrm{mol}$, and a generalized model for the activation energy $E_{a}^{\prime}=5629 \mathrm{~J} / \mathrm{mol}$.

By the results of comparing the most appropriate are the first and fourth models. The correlation coefficients are respectively 0,981 and 0,986 . As can be seen, for the calculation of indium viscosity it is enough to apply the model of general form (4).

Thus, the analysis of these models showed that the generalized model which took into account the degree of association of clusters viscosity molten metal is comparable with the temperature dependence of viscosity based on different content crystal sliding, liquid sliding and steam sliding particles has a high correlation coefficient, and is sufficient to describe the full range from the melting point to boiling point.

\section{The discussion of the results}

The new semi-empirical model of viscosity was tested for 28 common metals for which there are reference data about viscosity. With given the degree of association of clusters as the melt viscosity of the generalized model in a full range of temperatures from the melting point $T_{m}$ till the boiling temperature $T_{b}$ is possible to use the model (4) from the reference point $v_{r}$ and $T_{r}$ by kinematic viscosity of metal with finding a confidence interval and rounding. These equations are shown in Table 2.

Table 2

The equations of kinematic viscosity of metals

\begin{tabular}{|l|c|c|c|c|}
\hline \multicolumn{1}{|c|}{ Metal } & $T_{m,} \mathrm{~K}$ & $T_{r} \mathrm{~K}$ & $v_{r} \cdot 10^{7}, \mathrm{~m}^{2} / \mathrm{s}$ & Equation of kinematic viscosity \\
\hline \multicolumn{1}{|c|}{1} & 2 & 3 & 4 & 5 \\
\hline Lithium & 453.7 & 500 & 10.285 & $v=\left(0.561 \cdot 10^{-3} / T^{1.01}\right) \pm 3.14 \cdot 10^{-9}$ \\
\hline Sodium & 371 & 400 & 6.603 & $v=\left(0.216 \cdot 10^{-2} / T^{1.351}\right) \pm 2.74 \cdot 10^{-8}$ \\
\hline Kalium & 336.71 & 350 & 6.175 & $v=\left(0.792 \cdot 10^{-3} / T^{1.22}\right) \pm 2.78 \cdot 10^{-9}$ \\
\hline Cuprum & 1356 & 1438 & 4.85 & $v=\left(0.080 / T^{1.65}\right) \pm 8.02 \cdot 10^{-9}$ \\
\hline
\end{tabular}


Continuation of Table 2

\begin{tabular}{|c|c|c|c|c|}
\hline 1 & 2 & 3 & 4 & 5 \\
\hline Rubidium & 312.7 & 350 & 3.675 & $v=\left(0.479 \cdot 10^{-3} / T^{1.22}\right) \pm 1.66 \cdot 10^{-9}$ \\
\hline Argentum & 1235 & 1293 & 3.98 & $v=\left(0.183 / T^{1.82}\right) \pm 1.57 \cdot 10^{-9}$ \\
\hline Caesium & 301.6 & 350 & 2.913 & $v=\left(0.305 \cdot 10^{-3} / T^{1.19}\right) \pm 1.95 \cdot 10^{-9}$ \\
\hline Aurum & 1337.59 & 1336 & 3.11 & $v=\left(0.963 \cdot 10^{-2} / T^{1.44}\right) \pm 2.65 \cdot 10^{-9}$ \\
\hline Beryllium & 1560 & 1570 & 3.494 & $v=\left(0.864 \cdot 10^{24} / T^{9.51}\right) \pm 0.2$ \\
\hline Magnesium & 923 & 973 & 7.01 & $v=\left(0.337 \cdot 10^{2} / T^{2.57}\right) \pm 4.47 \cdot 10^{-9}$ \\
\hline Calcium & 1125 & 1173 & 10.81 & $v=\left(0.152 / T^{1.68}\right) \pm 1.37 \cdot 10^{-8}$ \\
\hline Strontium & 1043 & 1073 & 8.149 & $v=\left(1.010 / T^{2.01}\right) \pm 3.62 \cdot 10^{-9}$ \\
\hline Barium & 983 & 1073 & 4.564 & $v=\left(0.025 / T^{1.56}\right) \pm 1.68 \cdot 10^{-9}$ \\
\hline Zinc & 692.7 & 698 & 4.5 & $v=\left(0.117 / T^{1.90}\right) \pm 3.59 \cdot 10^{-9}$ \\
\hline Cadmium & 594 & 603 & 1.374 & $v=\left(1.360 \cdot 10^{-2} / T^{1.80}\right) \pm 1.21 \cdot 10^{-9}$ \\
\hline Mercury & 234.27 & 273 & 1.239 & $v=\left(0.192 \cdot 10^{-6} / T^{0.90}\right) \pm 1.59 \cdot 10^{-9}$ \\
\hline Aluminium & 933.4 & 973 & 4.75 & $v=\left(5.845 \cdot 10^{-4} / T^{1.03}\right) \pm 1.82 \cdot 10^{-11}$ \\
\hline Gallium & 302.92 & 326 & 3.11 & $v=\left(6.091 \cdot 10^{-5} / T^{0.91}\right) \pm 3.56 \cdot 10^{-9}$ \\
\hline Indium & 429.56 & 443 & 2.433 & $v=\left(8.389 \cdot 10^{-5} / T^{0.96}\right) \pm 3.06 \cdot 10^{-9}$ \\
\hline Thallium & 576 & 579.2 & 2.328 & $v=\left(1.001 / T^{1.32}\right) \pm 2.63 \cdot 10^{-9}$ \\
\hline Germanium & 1211.41 & 1218 & 1.35 & $v=\left(62.4 / T^{2.81}\right) \pm 7.09 \cdot 10^{-9}$ \\
\hline Tin & 505 & 573 & 2.23 & $v=\left(0.102 \cdot 10^{-3} / T^{0.97}\right) \pm 1.56 \cdot 10^{-9}$ \\
\hline Lead & 600.6 & 648 & 2.05 & $v=\left(0.341 \cdot 10^{-4} / T^{0.79}\right) \pm 5.75 \cdot 10^{-10}$ \\
\hline Bismuth & 544.2 & 548 & 1.95 & $v=\left(1.005 \cdot 10^{-3} / T^{1.36}\right) \pm 1.21 \cdot 10^{-9}$ \\
\hline Tellrium & 723.11 & 733 & 3.57 & $v=\left(31.17 / T^{2.77}\right) \pm 0.18 \cdot 10^{-7}$ \\
\hline Ferrum & 1811 & 1838 & 4.56 & $v=\left(1.586 \cdot 10^{5} / T^{3.54}\right) \pm 1.86 \cdot 10^{-9}$ \\
\hline Cobalt & 1767 & 1777 & 7.39 & $v=\left(5.962 \cdot 10^{3} / T^{3.05}\right) \pm 3.55 \cdot 10^{-9}$ \\
\hline Nickel & 1728 & 1803 & 6.09 & $v=\left(1.070 / T^{1.92}\right) \pm 5.98 \cdot 10^{-10}$ \\
\hline
\end{tabular}

5 metals (gallium, indium, tin, lead and mercury) have a mean value $\bar{a}<1$, when the main cause of it is the capability in supercooling at lower crystallization remain liquid. So gallium is able to remain liquid till $-40{ }^{\circ} \mathrm{C}(233 \mathrm{~K})$, indium is a chemical analogue of gallium and has good fluidity, tin and lead, also remain liquid at supercooling and mercury - only metal which is liquid in the standard state, has a melting point $-38.9^{\circ} \mathrm{C}$.

\section{Conclusions}

1. A new semi-empirical model of viscosity tested on 28 common metals for which there are reference data on the temperature dependence of viscosity. In most cases, generalized model describes the temperature dependence of the viscosity more adequately comparing with the experimental data than previously proposed three alternative models.

2. Obtained high values of correlation coefficients for the proposed model points to its functional characteristics. On this basis there were recommended calculated dependence for each metal.

3. For 5 metals (gallium, indium, tin, lead and mercury) received average meaning $\bar{a}<1$, which explains their tendency to remain in the supercooling in the liquid state. 


\title{
References
}

1 Вертман А.А. К проблеме металлических расплавов / А.А. Вертман // Фундаментальные исследования физикохимии металлических расплавов. Памяти академика А.М. Самарина. — М.: РКЦ «Академкнига», 2001. — 209 с.

2 Herwig F. Eine Schwingtiegelapparatur zur Bestimmung der Viskosität von Flüssigkeiten bei hohen Temperaturen / F. Herwig, M. Wobst // Metallik. — 1991. — Vol. 82, No. 12. - S. 913-916.

3 Bettezzati L. The viscosity of liquid metals and alloys / L. Bettezzati, A. Greer // Acta met. — 1989. — Vol. 37, No. 7. — P. 1791-1802.

4 Малышев В.П. Вязкость расплавов по концепции хаотизированных частиц / В.П. Малышев, А.М. Турдукожаева, А.Ш. Кажикенова // Тяжелое машиностроение. — 2009. — № 6. - С. 37-39.

5 Турдукожаева А.М. Вязкость жидких металлов с учетом природы вещества по концепции хаотизированных частиц / А.М. Турдукожаева, В.П. Малышев, А.Ш. Кажикенова // Новости науки Казахстана. — 2010. — № 2. — С. 32-35.

6 Свойства элементов: Справ. изд.: в 2 кн. Кн. 1 / Под ред. М.Е. Дрица. -3-е изд., перераб. и доп. — М.: Руда и металлы, 2003. - С. 448.

\section{А.Ш. Қажикенова, Д.Б. Әлібиев, Э.С. Ибраева \\ Тұтқыр сұйық металға кластерлі-ассоциативті модельді қолданудың тиімділігі}

\begin{abstract}
Сұйық металдарды ядролық энергетика, химия, космостық техника және өндірістің басқа да салаларында металлургиялық өнеркәсіптің қажеттілігі және заттардың жаңа технологиялары үшін жұмыс денелері мен жылу тасығыштары ретінде қолдану аймақтарының кеңеюі олардың жылу физикалық қасиеттерін, оның ішінде тұтқырлығын зерттеу мәселесінің өзектілігін айқындайды. Температураға байланысты тұтқырлықты сипаттау үшін физикалық мағынасын жоғалтатын төрт-бес жуықтау параметрлері бар трансцендентті полиномдарды қолданады. Осындай аппроксимациялық тәуелділіктерді зерттеген аралықтан оның $25 \%$ артық шамаға экстраполяциялау мүмкін емес екені белгілі. Себебі ондай полиномдарға тән экстремалдылықтардың шығуы мүмкін болады, ал олар тұтқырлықтың температуралық тәуелділігінің бірқалыпты кемімелі сипатына қайшы келеді. Әдетте, тәжірибелік нүктелер, әсіресе қиын балқитын және жоғары температурада қайнайтын металдар үшін, балқу нүктесіне түйісетін төменгі температуралық аймақтарға қатысты. Оған қоса әр металдың тұтқырлығы температураға өте тәуелді, сондықтан оның балқу нүктесінен қайнау нүктесіне дейінгі аралықта өзгеру барысында жуықтап алғанда төрт есеге азаяды. Баяндамада байлынысқан кластерлердің сұйық балқымаларға әсер ету деңгейін ескеретін, сұйық металдардың тұтқырлығын есептейтін жалпы модель келтірілген. Кристалданған бөлшектердің біркелкі моделінің сұйық күйіндегі элементарлық кластерінің балқыған металдың температуралық тұтқырлығының тәуелділігі анықталған. Тұтқырлықтың температурадан тәуелділігінің жалпыланған формасы металл ерітіндісінің ағын энергиясының құлшынысын санауға Френкель теңдеуімен бірге қолданылған. Жаңа жартылай эмпирикалық үлгісі тұтқырлық пен температура арасында тәуелділігі анықтамалық индий ерітіндісі арқылы көрсетілген. Ұсынылып отырған модель бойынша есептелген сұйық индий тұтқырлығының салыстырмалы нәтижесі берілген.
\end{abstract}

Кілт сөздер: тұтқырлық, ретсізделген бөлшектер, ассоцирленген кластердің дәрежесі, кластерліассоциативті моделі, сұйық металдар, реперлік нүкте, кристалқозғалысты бөлшектер, тұтқырлықтың температураға тәуелділігі.

\author{
А.Ш. Кажикенова, Д.Б. Алибиев, Э.С. Ибраева
}

\section{Эффективность применения кластерно-ассоциатной модели кинематической вязкости жидких металлов}

Расширение областей использования жидких металлов в качестве рабочих тел и теплоносителей в ядерной энергетике, химии, космической технике и других отраслях промышленности, для потребности металлургического производства и новых технологий материалов делают задачу исследования их теплофизических свойств, и в частности вязкости, актуальной. Для описания вязкости в зависимости от температуры часто используют трансцендентные полиномы с четырьмя-пятью подгоночными параметрами, лишенными физического смысла. Как известно, экстраполяция подобных аппроксимирующих зависимостей невозможна более чем на $25 \%$ от изученного интервала ввиду неизбежных проявлений экстремальностей, характерных для таких полиномов, которые полностью противоречат монотонно убывающему характеру температурной зависимости вязкости. Как правило, экспериментальные точки относятся к низкотемпературной области, примыкающей к точке плавления, особенно 
для тугоплавких и высококипящих металлов. Между тем вязкость каждого металла сильно зависит от температуры и при ее изменении от точки плавления до точки кипения уменьшается приблизительно в четыре раза. Целью нашего исследования является разработка кластерно-ассоциатной модели вязкости жидких металлов на основе концепции хаотизированных частиц в зависимости от степени ассоциации кластеров. В статье рассмотрена температурная зависимость вязкости согласно концепции хаотизированных частиц. Проанализированы модели зависимости вязкости от температуры с учетом различного содержания частиц: кристаллоподвижных, жидкоподвижных и пароподвижных частиц. Предложена новая кластерная модель температурной зависимости вязкости, позволяющая выявить поведение вязкости в широком диапазоне температур. Показана применимость данной модели на примере расплава индия.

Ключевые слова: вязкость, хаотизированные частицы, степень ассоциированности кластеров, кластерно-ассоциатная модель, жидкие металлы, реперная точка, кристаллоподвижные частицы, температурная зависимость вязкости.

\section{References}

1 Vertman, A.A. (2001). K probleme metallicheskih rasplavov [On the problem of metal melts]. Fundamentalnye issledovaniia fizikohimii metallicheskih rasplavov. Pamiati akademika A.M. Samarina - Fundamental studies of physical chemistry of metal melts. In memory of Academician A.M. Samarin. Moscow: Akademkniga [in Russian].

2 Herwig, F., \& Wobst, M. (1991). Eine Schwingtiegelapparatur zur Bestimmung der Viskosität von Flüssigkeiten bei hohen Temperaturen. Metallik, 82, 12, 913-916.

3 Bettezzati, L., \& Greer, A. (1989). The viscosity of liquid metals and alloys. Acta met., 37, 7, 1791-1802.

4 Malyshev, V.P., Turdukozhaeva, A.M., \& Kazhikenova, A.Sh. (2009). Viazkost rasplavov po konceptsii haotizirovannyh chastits [The viscosity of liquid metals based on the nature of the substance of the concept of randomized particles]. Tiazheloe mashinostroenie - Heavy Engineering, 6, 37-39 [in Russian].

5 Turdukozhaeva, A.M., Malyshev, V.P., \& Kazhikenova, A.Sh. (2010). Viazkost zhidkih metallov s uchetom prirody veshhestva po konceptsii haotizirovannyh chastits [The viscosity of liquid metals based on the nature of the substance of the concept of randomized particles]. Novosti nauki Kazakhstana - News of Kazakhstan science, 2, 32-35 [in Russian].

6 Drits, M.E. (Eds.). (2003). Svoistva elementov [The properties of the elements]. (In 2 books. Book 1. 3d ed.). Moscow: Ruda i Metally [in Russian]. 